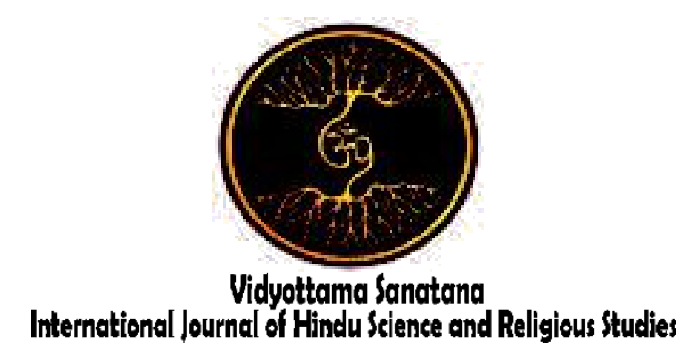

Vol. 2 No. 2 October 2018

\title{
Procession Of Pujawali Mupuk Kembang At Pura Agung Banjar Adat Gegadon: Hindu Religion Edudcation Values
}

\author{
By: \\ Ni Made Rai Setyawati ${ }^{1}$, I Made Suastika ${ }^{2}$, Made Iwan Indrawan Jendra ${ }^{3}$ \\ ${ }^{13}$ Institut Hindu Dharma Negeri Denpasar \\ ${ }^{2}$ Udayana University, Denpasar \\ E-mail: ${ }^{1}$ rai.setyawati@yahoo.com
}

Received: June 19, 2018

Accepted: September 11, 2018

Published: October 31, 2018

\begin{abstract}
One of the ways taken by Hindu people to keep the harmony and prosperity in the world is by performing yajña. It is being exercised by krama Custom Banjar of Gegadon Kapal by conducting a ritual of pujawali at the Great Temple of Custom Banjar Gegadon. The temple is a small temple but enthroned by Ida Ratu Gede Sakti. The Pujawali is performed exactly on the day of budha kliwon wuku Pahang. This research discusses: (1) The form of procession of Pujawali Mupuk Kembang at the Great Temple of Custom Banjar Gegadon, Village of Kapal, District of Mengwi, Regency of Badung. (2) The function of procession practice of Pujawali Mupuk Kembang at the Temple (3) The Hindu religious education valuecontained in the procession. The theories being used in this research includ: 1) Structural functional theory, 2)Religious Theory, 3) Value Theory. The type of the research is descriptive qualitative. The primary sources for the data are congregation figures, religious figures andpublic figures, and its secondary sources are in the form of research results of books, articles, which are related with pujawali practice. The research instrument is interview guideline by using purposive technique, observation and documentation, the analysis technique, descriptive. The result of the research can be concluded as follows: (1) The procession of Pujawali Mupuk Kembang is a series of pujawali ritual from the beginning until the endwhich is closed with nyineb ceremony, (2) The function of pujawali consists of education, social, and religious function, (3) The values contained within pujawali procession is Hindu Religious education values namely tattva, ethic and ceremony.
\end{abstract}

Keywords: Pujawali Mupuk Kembang and Hindu Religious Education. 


\section{INTRODUCTION}

Yajna ceremony implemented by Hindus sourced from sacred Vedic literature. The charge of education in the implementation of the yajna ceremony through the Panca Yajna ceremony. Hindu Religious Education can also be given with regardthe concept of Tri Hita Karana.

Harmonious relationship between human and human is manifested in social life. A harmonious relationship with the environment is realized by preserving the natural surroundings. Harmonious relationship with God can be realized by prostration devotion to God, with the building of temples and the sacred or ceremonial Yajna.

Harmonious relationship between human and Sang Hyang Widhi can be implementedwithDewa yajna ceremony as practiced by krama panyungsung Pura Agung Banjar Adat Gegadon Kapal village. Implementation of the procession can be used as a medium of education tattva, susila, and acara for the community and also to the younger generation as the successor to the culture that has a great value. Aside from that, the presence of this study are many things that can be studied in the implementation of the ceremony such as the design, function and value of the implementation of the procession Pujawali Mupuk Kembang .

Mupuk Kembang procession is a series of rituals pujawali held from 18:00 pm or when the sun began to sink atpiodalan until sunrise the next day about $06.00 \mathrm{pm}$. Ritual performed on an ongoing basis with the aim to beatify Him bersthana in the Pura Agung and invoke fertility, progress and development of the thoughts, words, and actions that lead to goodness, to perfection, so that His Asung Kertha wara nugraha towards all beings, the earth and its contents

Pujawali Mupuk Kembang procession held every 120 days, exactly on Buddha Kliwon wuku Pahang. Mupuk Kembang procession held in the Pura Agung Banjar Adat Gegadon Kapal village filled with many religious symbols. There are some uniqueness in this procession so the author interested to conducting research such as:

1. Pura Pura Agung as one Papeletan (small temple disungsung by krama panyungsung Banjar Adat Gegadon) have the meaning or the enormous influence of the other temples in the environment Kapal village like in Desa Adat Kapal Temple.

2. The existence of ritual mabaos by one patapakan in Pura Agung when pujawali

3. The ritual be held from 18:00 pm on Wednesday (Buda Kliwon Wuku Pahang) until $06.00 \mathrm{pm}$ the next day.

4. Ritual ngunying closed by pamangkuPura Agung Banjar Adat Gegadon, as a sign of approval or the end of a series of pujawali , which is usually not done by pamangku at others temple as there is in the Pura Agung Banjar Adat Gegadon when pujawali .

Various forms of upakara are made and ritualthat performed when pujawali as offerings to invoke blessings and grace of God. Basically these diverse forms have each of meaning and function.

\section{Methods}

This study used a qualitative approach, by taking a research location in the Pura Agung Banjar Adat Gegadon, Kapal, Mengwi, Badung. Is the primary source of community leaders, religious leaders and community leaders and secondary sources in the formof research books, articles, relating to the implementation of the pujawali. Research instrument by interview guide. Technical determination of informants with sampling techniques. Data collection techniques with interview, observation and documentation. The data has been analyzed and then presented through qualitative descriptive technique by using Religi Theory, Theory of Structural Functionalism, Symbolic interactionism Theory and Theory of Value. 


\section{Results And Discussion}

The history of the construction of the Pura Agung with Pujawali Mupuk Kembang procession, is inseparable from theincidentthat had happened villagers attacked Indigenous Kapal plague endlessly. Finally, residents of the Kapal villageinvoke recovery in Pura Desa. In that invoke, the resident of Desa Adat Kapal vows, if the healing endowed by the Almighty with His manifestations, then the citizens will be able to doyajna in Pura Desa AdatKapal. While, the elders in Banjar Adat Gegadon doing a series of rituals when pujawali all night called mayasa Kerti, to invokehealing for the people of Banjar Adat Gegadon, and also healing for the entire residents of Kapal village. Afterpujawali , appears indication that people receive healing and condition of all residents of Kapal villagebe better.

With the blessing of healing obtained all residents, then the community ofBanjar Adat Gegadon build Pura Agung and implement pujawali by offering a variety of rituals all-night, which is called the Mupuk Kembang (Interview with I Wayan Wenten, August 25, 2014). Pujawali implementation, have a certain order in accordance with the ethical teachings of Hinduism, starting from the physical cleaning of holy places, ngunggahang upakara in each palinggih, and arranging upakara ayaban will be offered.

The BeginningPujawali procession held in the Pura Agung Banjar Adat Gegadon, is nunjel penimpug (burn penimpug), offering bayekawonan, offering pangulapan, prayaścitta and panyepuhan in every banten and palinggih, ngias ring Joli and Daksina Palinggih, nedunang Ida Bhatara, ngaturang rayunan, Pamangku and Pamaksan prepare the Joli and all Daksina Linggih back tedun disungsusng by patapakan to be implemented ngabijiang ritual. After coming from ngabijiang there is Maica-ican (fun) ritual and the last is ngalinggihang Ida Bhatara

Core procession include: ngaturang pacaruan (offeringcaru), ngamargiang pathirthan (implementation pujawali ) praying togrther, ngrejangritual, pependetan (wali ngawaliang Pujawali n Ida Bhatara), at 5:30 pm offering ajang linggih, at 5:45 pm nglebar preparation, nglebar, aedan nyejer tigang rahina (for three days). Final procession include: praying together ceremonies, and nyineb ceremonies..

Pujawali Mupuk Kembang procession at Pura Agung Banjar Adat Gegadon Kapal village led by Sulinggih, and assisted by Pamangku in sluhur namely Mangku Wayan Kertia, Mangku in Pura Marga TigaI Nyoman Sudarsana, Mangku in Pura Kentel Bumi that I Wayan riden, Mangku in Pura Beji.

Upakara quantity used when pujawali in Pura Agung Banjar Adat Gegadon is madya quantity. Utamaning utamaquantity implemented when pujawali coincide with the Purnama / Tilem. However, when the researchers examined levels of the upakara that is the madia quantity because its not coincide with the Purnama / Tilem. Upakara types are used when pujawali among others: penimpug, byakawonanan, prayaścitta-sakti, pangulapan, panyepuhan, banten sane munggah (placed) in each palinggih: bantensoda, bantendaksina, daksina linggih (daksina palinggih), peras, suci alit, dapetan ajang linggih. Banten placed in sambiangan (Piasan) consisting of: polo gembal, taman, teteg, banten ancak, banten bingin, jerimpen, gebogan, Pasucian, penyeneng,banten are placed / offering below (the court of the temple), sorohan, tegen-tegenan (Salaran), segehan cacahan, segehan agung, gelar sanga. Upakara in the holy kitchen, bantenpejati asoroh, suci alit asoroh, Anten ayaban tumpeng 7 bungkul, banten tumpeng abang, soda abang, meulam ayam biying mapanggang.

Mantra used by the master of ceremonies adjusted with a barrage of ongoing pujawali ritual.Pujawali led by a sulinggih, assisted by some pemangku that exist in Banjar Adat Gegadon.

Human life in this world shall remember their obligation to the God Almighty because He has sacrificed through Hisyajna, so that humans can develop and 
enjoy all of God's creation. Humans who do not know thanks for the mercy of God is sinful creatures who deserve the misery in the world and in the hereafter. As described in the literature Bhagavadgita, III. 10 as follows:

\section{Saha-yajñàá prajàá såûpvà \\ Purovàca prajàpatiá, Anena prasaviûyadhvam \\ Eûa vo 'stviûpa-kàma-dhuk. Translation:} really since the first said, after God created humans by way ofyajna, said: by this (way) you will have to evolve, as well as dairy cattle that meet the desires (own) (Pudja, 2010: 84).

Moving on from the above, in everyday life implemented as a form of liability that actualized through the implementation of a ceremony, which mostly oriented on the use of Banten. In Lontar Dewa Tattwa, explained that thebanten is the embodiment of God Almighty, so the structure of Banten at a ceremony also serves as the embodiment that recognize the existence of kanista, Madhya, Uttama. The offerings are often associated with religious activities or customs. Every religion justifies every followers to do an offering that caused there is a change in attitudes, especially inner attitudes increasingly safe and quiet.

Banten is not food to be presented to God Almighty. Banten is the language of sacred symbols in the eyes of the Hindus. As a language symbols Banten is a medium to visualize the teachings of Hinduism. As a medium for conveying sradha and devotion to the omnipotence Hyang Widhi. Banten as well as local cultural forms that are very sacred in which there are universal values. The main thing is Banten as a language symbols is not contrary to the essence of the truth of the Weda. Because he sets the mood of the most deep, as revealed by Gertz (1992) that the symbol that motivates human beings to formulate concepts that mood can be a reality.

Educational function in the Pujawali Mupuk Kembang procession is the transformation of knowledge as a result of the educational process wrapped up in religious tradition and passed down from generation to generation in the context of local wisdom.

Social function in the procession pujawali, seen not only in the form of control words that always arranged carefully, paying attention to the sacred element because it is the religious atmosphere, but is also evident in the form of Krama Banjar Adat Gegadon effort to unite ideas and the ideas and coordinate with each other in the realm of cooperation in order to prepare a variety of infrastructure required in the course of the ceremony on the Mupuk Kembang procession.

Aesthetic function in this case serves to create a sense of peace and peace in the human soul, so it will have implications for the emergence of a sense of sincere devotion to Ida Sang Hyang Widhi Wasa and a sense of togetherness among humans.

Implementation of religious ceremonies have cultural functions implications for society. Similarly, in the implementation of the Pujawali Mupuk Kembang have cultural functions as an act of Hindus in Banjar Adat Gegadon in applying the doctrine of Hinduism.

Pujawali implementation of the management functions in the Pura Agung Banjar Adat Gegadon can be seen from the Tri Manggalaning yajna in that ceremony. Tri Manggalaning yajna which consists of the Sang Yajamana or who have Yajna, the Sang Sarathi and the Sang Mangala or master of ceremonies in this case could be a pamangku or sulinggih. The three are interdependent and complementary.

Hinduism can be explained by sraddha, because sraddha is the framework that forms the basis of the doctrine in the Hindu religion needs to be believed and lived with understanding. Education of the truth or Tatwa Hinduism in Pujawali Mupuk Kembang procession for society Banjar Adat Gegadon, Kapal Village, Mengwi District,Badung Regency, is a form of belief or faith (sraddha). Shraddha is a trust or confidence which is based on 
religion. Religion provides knowledge about the purpose of life and the right path and give respect for life after death. Religion can be also a motivation to do a good deed, so that religion is used to handle on life as it will be able to give you peace of heart and liberate humanity from the darkness in life.

Human is a perfect human beings among all creatures of God's creation. Because if compared to other human beings have the advantage that the mind (Idep) with the ability to think humans can distinguish between good and bad that can change and improve their lives. Sārasamuccaya 2 states as follows:

Ri sakwehning sarwa Bhuta, iking janma wwang juga wënang gumawayaken ikang úubhàúubha karma, kuneng panëntasakëna ring úubhakarma juga ikang aúubhakarma phalaning dadi wwang. Translation:

Among all living beings, just born to be human, which can carry out good deeds or bad, destroyed into good deeds, all the bad deeds; so the point (the reward) become human (Kadjeng, 2010: 8).

Hinduism guiding people to achieve happiness and perfection. Sacred doctrine tends to moral education and character of human. Religion seeks to foster the people to be moral and benevolent man who uses his dharma as guidelines. Although uneducated, and poor property, but if the rich nobility like and then the heaven door and mokshawill be open.

The value of Pujawali procession ceremony at Pura AgungBanjar Adat Gegadon is an attempt to build harmony of human with God by way: Bhakti, with fellow human beings (Punia), and humans with the environment (Asih). One of divisualisaikan into various forms of banten, because in implementationpujawali processbantenor upakara is crucial to achieve trasent or kerauhan, and therefore society Banjar Adat Gegadon very confident that the banten were used during the Mupuk Kembangprocession should be in accordance with the provisions of which has been applicable if you want the ceremony goes according to the expectations of society.

\section{Conclusion}

Based on the analysis of processes, functions and values contained in the implementation of the pujawali in Pura Agung Banjar Adat Gegadon, the research conclusions can be drawn as follows.

1. Implementation of the Pujawali Mupuk Kembang procession is a series of implementation in the pujawali at Pura Agung Banjar Adat Gegadon implemented by krama panyungsung Pura Agung. The procession is implemented with a variety of uniqueness that is not contained in the other temple rituals in Desa Adat Kapal.

2. Pujawali procession in Pura Agung has several functions that include: (1) religious functions; as the form of increased sraddha and devotion people against the Almighty, (2) education; as a form of non-formal education can be create the character of the people from tattva education, ethics, and ceremonies, (3) social function; as a form of social interaction in the ceremony, (4) the function of aesthetics; as a way to create beauty in form medium of beautifulupakaraand can give subtlety of the soul, (5) cultural functions; so that the Pujawali Mupuk Kembang procession still implemented by krama panyungsung Pura Agung Banjar Adat Gegadon Kapal, (6) the function of management skills; can teach people in managing a ceremony in the community.

3. The educational values of Hinduism contained in pujawali implementation in the Pura Agung is (1) the value of tattvaeducation; is how Hindus can perform the piodalanceremony thatSatwika accordance with the sources of Hindu religion, so that it can bring a good reward for Hindus itself. (2) The value of education ethics / 
morality; ethical and moral formation of the citizens when pujawali so pujawali can be done well without any unrest among the citizens, and as learning so that people can still behave in an ethical and polite in everyday life, forming harmony in social life. (3) The value of educational events; Of the implementation ofpujawali Hindu community in Banjar Adat Gegadon can move to implement ritual pujawali in concept ngayah with a sincere heart and a peaceful heart, so thereby realizing peace in society. From some education that obtained from implement of Pujawali Mupuk Kembang be obtained shanti jagadhita life that can be felt by the people panyungsung Pura Agung and the wider community in Desa Adat Kapal.

\section{References}

Gie, The Liang. 2004. Filsafat Keindahan. Yogyakarta: Pusat Belajar Ilmu Berguna (PUBIB).

Kadjeng, I Nyoman. 1993/1994. Sarasamusccaya. Denpasar: PEMDA Tingkat I Bali.

Parisada Hindu Dharma Pusat. 2002. Himpinan keputusan seminar kesatuan tafsir terhadap aspek-aspek agama hindu I-XV. Pemprop Bali.

Sudarsana, I.B Putu. 2005. Ajaran Agam Hindu Upacara Dewa Yadny. Denpasar: Yayasan Dharma Acarya.

Wiana, I Ketut. 2007. Tri Hita Karana: Menurut Konsep Hindu. Surabaya: Pāramitha. 